\title{
Yasal Düzenlemelerin Borsa İstanbul'da Sektörel Etkisi: Sigorta Sektörü Örneği
}

\section{Sectoral Effect of Legal Regulations on Stock Exchange in Istanbul: Example of Insurance Sector}

\section{Dr. Öğr. Üyesi Fatma Davarcıoğlu Özaktaş ${ }^{1}$}

Başvuru Tarihi: 15.02 .2018

Kabul Tarihi: 26.09.2018

Öz

Çalışma, sigorta sektörüne yönelik beş yasal düzenlemenin Borsa İstanbul'da işlem gören sigorta şirketlerinin hisse senedi getirilerinde normal üstü getiriler oluşturup oluşturmadiğını araştırmayı amaçlamaktadır. Analiz yöntemi olarak olay çalışması benimsenmiştir. Tahmin penceresinin 150 gün, olay penceresinin $(-10,+10)$ olduğu çalışmada, olay günü, düzenlemelerin yürürlük tarihleridir.

Analiz sonuçlarına göre, beş olaydan sadece birinde sektör yatırımcısı normal üstü getiriler elde edememiştir. Diğer dört olayda, istatistiksel olarak anlamlı normal üstü ve kümülatifnormal üstü getiriler să̆landı̆̆ı gözlemlenmiştir.

Anahtar Kelimeler: Sigorta sektörü, Firma değeri, Etkin Piyasalar Hipotezi, Anormal Getiriler, Olay Çalışması

\begin{abstract}
The study aims to investigate the role of five legal regulations on the insurance companies traded in the Istanbul Stock Exchange, whether they provide abnormal returns on stocks. Event study was adopted as analysis method. 150 work days were taken into account as event window. The date on which the laws entered into force were determined as event days and event window was constructed by establishing 10 days before and after the event days.

According to the analysis results, the sector investor, has not been able to get abnormal return on just one event. In other four cases, statistically significant abnormal and cumulative abnormal returns were observed.
\end{abstract}

Keywords: Insurance Sector, Firm Value, Efficient Market Hypothesis, Abnormal Return, Event Study

${ }^{1}$ Abant İzzet Baysal Üniversitesi İIBF, davarcioglu_f@ibu.edu.tr, ORCID: 0000-0002-3528-8329 


\section{Giriş}

Firmalar için halka arz olmak ve hisse senetlerinin talep görmesi büyük önem taşımaktadır. Halka arz olmak, kurumsallaşma, itibar, kredibilite artışı, nitelikli insan gücüne erişime kadar pek çok alanda katkı sağlamanın yanısıra asıl olarak, cazip bir finansman kaynağı olarak hem likiditeyi hem de güçlü bir mali yapıyı getirmektedir.

Hisse senedi yatırımcıları ise, makro ve mikro faktörleri değerlendirmektedirler. Dünya ekonomilerinin tümünü ilgilendiren küresel bazda olaylar tüm finansal piyasayı etkilerken, mikro faktörler doğrudan sektör ve firma ile ilgilidir. Yatırımcıların talebini etkileyen en önemli unsur, firmanın kazancıdır, zira kar elde etmeyen bir firmanın yatırımcısı tatmin olmayacaktır. Ancak ilk bakışta, sadece finansal tablolar çerçevesinde kararlar alındığını yansıtan bu ifade arkasında pek çok bilgiyi barındırır. Çünkü firmanın karlılığı, firma yönetim başarısı, arge faaliyet payı, gelecek yatırım planları, yasal düzenlemelerden nasıl etkileneceği gibi pek çok öğeye de bağlıdır.

Yatırımcı, her ne kadar sektörün/firmanın geçmiş performansı ve tüm bu gelişmeleri dikkate alsada, asıl olarak tüm bu gelişmeler karşısında sektörün/firmanın nasıl etkileneceğine dair beklentisiyle de yatırım kararı verir. Bir başka ifadeyle, finansal piyasalarda yatırımcının beklentisi oldukça önemli bir belirleyendir. Beklentiler ve geçmiş verilerle yatırım analizi yapılarak daha fazla getiri elde etme isteği yatırımcının ana hedefidir (Gümrah ve Belen, 2016, s.429).

Diğer yandan, sektörü yada doğrudan firmayı etkileyen 'olay' niteliğindeki yasal düzenleme, birleşme, satın alma, kurumsal derecelendirme notları, beklenmedik haberler gibi durumlarının yatırımcı için fazladan bir kazanç sağlayıp sağlamadığı konusunda farklı görüşler bulunmaktadır.

Teorisi gereğince fiyatların piyasaya ulaşan bilgi doğrultusunda düzeltme yapması gerektiğini iddia eden etkin piyasalar teorisinin, test edilmesinin bir yolu da olay çalışmasıdır. Zira olay çalışması herhangi bir olayın fiyatlar üzerindeki yansımasını istatistiki olarak ölçmeyi amaçlar. Ancak çalışmanın ana teması hisse senedi piyasalarındaki etkinliği ölçmek değildir.

Bu çalışmanın amacı,sigorta sektörüne yönelik bazı yasal düzenlemelerin sektöre yansımasını, firma değerine nasıl yansıdığını dolayısıyla sektör yatırımcısını nasıl etkilediğini, normal üstü getiri elde edip edemeyeceğini tespit etmektir. Sigorta sektörünün seçilmiş olması ise, sektörün toplumsal boyutlu hizmet sağlaması nedeniyle kamu düzenlemelerine birçok sektöre göre daha fazla maruz kalmasından ileri gelmektedir.

Bu doğrultuda çalışma dört bölümden oluşmaktadır. İlk bölümde, olay çalışmasına ilişkin literatüre yer verilmiş ardından olay çalışması sonuçlarını yorumlayabilmek için öncelikle etkin piyasalar hipotezi aktarılmıştır. Bu kısmı uygulama kısmı izlemiş ve çalışmanın amacı doğrultusunda alınan olaylar, veriler, yöntem ile hipotezler açıklanarak, bulgu ve değerlendirmelerle son bulmuştur. 


\section{Literatür Özeti}

Olay çalışması analizi, elde edilen bir bilgi yada meydana gelen bir olay karşısında piyasanın verdiği olağandışı tepkiyi ölçmede kullanılmaktadır.

Menkul kıymetler piyasasında işlem gören farklı sektörlerin varlığı ve hisse senedi piyasasını etkileyen bilgi yada olayların çeşitliliği, olay çalışması literatürünü büyük ölçüde genişletmiştir. Bu konuda öncü çalışmalardan ilki, Dolley’in (1933) 1921-1935 yıllarını kapsayan 95 şirketin kullanıldığı hisse bölünmesinin fiyatlara etkisini incelediği çalışmasıdır. Çalışmada, olayların 57'sinde fiyatın arttığını, 26'sında fiyatın azaldığını, 12'sinde ise etkisinin olmadığı bulunmuştur. Yine benzer bir konuyu işleyen diğer bir öncü çalışma, Fama, Fisher vd. ait olan 1969 yılı çalışmasıdır. Çalışma açıklama sonrasında, hisse senedi piyasasında fiyatlarda meydana gelen en büyük değişimin duyurunun yapıldığı haftada gerçekleştiği sonucuna varmaktadır. Fama 1970 yılında yaptığı çalışmada etkin piyasa hipotezini de ortaya koyarak literatürü daha da genişletmiştir (Derin ve Kütük, 2016, s. 310, Mazgit, 2013, s. 231).

Banka yada şirket birleşme ve devralma haber ve duyurularının borsaya etkisini inceleyen çalışmalara Çukur ve Eryiğit (2006), Yılmaz (2010), Hekimoğlu ve Tanyeri (2011), Çevikçelik (2012), Şahin ve Doğukanlı (2015), Şimşir (2016) örnek gösterilebilir.

Türkiye bankacılık sektöründe 2005 yılında ortaya çıkan birleşme ve devralma olaylarının etkisini ölçmeyi amaçlayan çalışmada, Çukur ve Eryiğit (2006), birleşme ve devralma niyetlerinin kamuya açıklanmasının borsada olumlu karşılandı̆̆ı, pozitif, anlamlı anormal getiriler ortaya çıktığı, ayrıca, bu fazlalık getirilerin geçici olmaktan ziyade kalıcı özelliklere sahip olduğunu raporlamıştır.

2010 yılında 2002-2003 dönemi için 51 adet şirketi alarak birleşmenin etkisini yine aynı yöntemle ortaya koyan Yılmaz (2010), birleşmenin açıklanmasından önce istatistiksel olarak anlamlı pozitif aşırı getiriler olduğu sonucuna varmıştır.

Türkiye'de 1991 ile 2009 yılları arasında halka duyurulan birleşmelerin ve kısmi satışların hedef şirket hisse senedi fiyatları üzerindeki etkileri inceleyen bir diğer çalışma Hekimoğlu ve Tanyeri'ye (2011) aittir. Hedef şirket hissedarlarının, halka duyuru gününü merkez alan üç günlük zaman aralığında, birleşme ve kısmi satışlarda kümülatif anormal getiri elde ettikleri belirtilmiştir.

2005-2011 yılları arasında birleşme ve devralmaya konu olmuş finans sektörü dışındaki şirketler üzerinde yapılan Çevikçelik (2012) çalışması, birleşmelerin genel olarak hisse senedi fiyatlarına kısa vadeli etkilerinin olduğunu ortaya koymuştur.

2002-2012 yılları arasında 13 bankayı ele alan Şahin ve Doğukanlı (2015) çalışmasında ise, duyuru tarihinden önce hisse senedi fiyatlarının arttığ 1 , duyuru tarihinden sonra ise getirilerin negatife dönüştüğü belirtilmektedir. 
Şimşir (2016) çalışması da, benzer şekilde birleşme ve devralmaların hisse senedi fiyatlarına yansıdığı sonucunu elde eden bir diğeridir.

Şirketlerin endeks kapsamında olmasının hisse senedi getirilerine etkisi (Mazgit 2013), gönüllü bazı açılamaları (Babacan ve Özer 2013), kazanç açılamaları (Güvercin ve Yusuf 2015), bedelli/bedelsiz sermaye artırımları (Çukur ve Eryiğit 2007; Küçüksille ve Mizrahi 2015), yatırım duyuruları (Elbir ve Kandır 2017), bankalar için sendikasyon kredisi kullanımının hisse senedi getirilerine etkisi (Sakarya ve Sezgin 2015) de literatürde geniş yer almıştır.

Mazgit (2013), BIST Temettü 25 endeksinde yer alan şirketler üzerinde yaptığı çalışmada, bu endeks kapsamında yapılan değişikliklerin hisse senedinin fiyat performansı üzerinde önemli bir etki yapmadığ 1 sonucuna ulaşmıştır.

Hisse senetleri İMKB 100 endeksinde işlem gören banka ve diğer finansal kurum dişındaki firmaların gönuillü açıklamalarının, hisse senedi getirileri üzerindeki etkisini olay etüdü ile inceleyen Babacan ve Özer (2013), gönullü açıklamaların hisse senedi getirilerini etkilediğini, bu etkinin özellikle sunduğu mal ve hizmetin teknolojik değişim hızı ve dolaşımdaki sermayesi düşik olan firmalarda ortaya çıktığı sonucuna varmıştır.

Şirketlerin kazanç açıklamalarının şirket değeri üzerindeki etkisi araştıran Güvercin ve Yusuf (2015), 2009-2013 yılları arasında BIST 100 endesksinde listelenen 78 şirketi örnek almış ve beklentilerin aksine kazanç açılaması sonrası şirket değerinin düştüğü sonucuna varmıştır.

Şirketlere dair diğer bir durum olan bedelli, bedelsiz sermaye artırımlarının etkilerini yine aynı yöntemle analizini konu alan Çukur ve Eryiğit (2007) çalışması, İMKB'de 2000-2005 yılları arasında yatırım ortaklığı sektöründe ortaya çıkan bedelsiz sermaye artırımları için istatistiki olarak anlamlı anormal getiri ve/veya kümülatif anormal getiriler tespit edilemediğini belirtmiştir.

Bedelli sermaye artırımı duyurusu üzerinde çalışan bir diğer çalışma 2010-2014 yılları arasında hisse senetleri BIST Hisse Senetleri Piyasası'nda işlem gören işletmeleri alan, Küçüksille ve Mizrahi'ye (2015) aittir. Elde edilen bulgulara göre; bedelli sermaye artırımı duyurusunun yapıldığı tarihte, duyurudan bir gün sonra, dört gün ve dokuz gün sonra istatistiksel olarak anlamlı ortalama negatif anormal getiriler elde edildiğini göstermektedir.

Elbir ve Kandır (2017), demir çelik sektöründe payları Borsa İstanbul'da işlem gören yedi şirketin 2005-2015 yılları arasındaki 23 adet yatırım duyurusunun pay getirileri üzerindeki etkisini incelemiş ve sözkonusu duyuruların pay getirilerinde anormal getiriye neden olduğunu göstermiştir. Ayrıca, pay getirilerinin yatırım duyuruları öncesinde arttığı belirlenmiştir.

Olay çalışması yöntemiyle şirketlere dair yapılan bir diğer çalışma örneği, hisse senetleri BIST’de işlem gören ve 2010 ile 2013 tarihleri arasında sendikasyon kredisi anlaşması imzalamış bankaların bu anlaşmalara dair yapmış oldukları özel durum açıklamalarının, hisse senedi 
getirilerini ne yönde etkilediği ve anormal getirilerin elde edilip edilemeyeceğinin belirlenmesi amacıyla Sakarya ve Sezgin (2015) tarafından yapılmıştır. Analiz sonucunda, bankaların sendikasyon kredisi anlaşmalarına dair açılamalarının hisse senedi getirilerini pozitif yönde etkilediği, pozitif anormal getirilerin elde edildiği gözlemlenmiştir.

Şirketler üzerine yapılan diğer çalışma konuları ise, aracı kurum tavsiyelerinin (Badalova vd., 2017), denetim görüşlerinin (Aygören ve Uyar 1997), kurumsal yönetim endeksi kapsamındaki şirketlerin kurumsal yönetim derecelendirme notlarının (Sakarya, 2011) hisse senedi getirileri üzerindeki etkisidir.

Badalova vd. (2017), olay çalışması yöntemini kullanarak Borsa İstanbul'da yer alan hisse senetlerine yönelik borsa uzmanları tarafından 2007-2015 yılları arasında yapılan hisse senedi tavsiyelerinin hisse senedi fiyatları üzerindeki etkisi incelemektedir. Yapılan analizde, kısa vadede aracı kurumların hisse alım satımı ile ilgili tavsiyeleri ile hisse senedi fiyatları arasında anlamlı bir ilişkinin olduğu, olay sonrası kısa vade de hisse senetlerinden anormal getiri elde edilebileceği tespit edilmiştir.

Aygören ve Uyar (1997) ise, İMKB'da işlem gören 101 adet şirketin 2004 ve 2005 yıllarına ait denetim raporlarının hisse senedi getirileri üzerindeki etkileri için yine aynı yöntemle anormal getirilerin varlı̆̆ını elde etmişlerdir.

Sakarya (2011), İMKB'de işlem gören ve 2009 yılında ilk defa yeterli kurumsal derecelendirme notu alarak İMKB Kurumsal Yönetim Endeksi'ne giren şirketlerin, derecelendirme notlarının ilanı ile hisse senedi getirileri arasındaki ilişki incelemiştir. Analiz sonucunda, iyi kurumsal derecelendirme notunun ilanı ile hisse senedi getirisi arasında pozitif bir ilişki olduğu, anormal getirilerin elde edilebileceği belirtilmiştir.

Yukarıda verilen olay çalışması örneklerine yasal düzenlemeleri de ekleyebilmek mümkündür. Leasing sektöründe $k d v$ oranı değişikliğinin İMKB'de işlem gören leasing şirketlerinin hisse senedi getirisine etkisi Koçyiğit ve Kılıç (2008) tarafından incelenmiş ve olay öncesi ve sonrası, istatistiksel olarak anlamlı anormal getirilerin elde edilmesinin mümkün olduğu sonucuna varılmıştır.

Kurumlar vergisi oranındaki değişikliğin hisse senedi getirileri üzerindeki etkisinin incelenmesini alan Kandır ve Yakar (2012) ve Güre ve Kütük (2016) yasal düzenleme konusundaki diğer örneklerdir. Olay çalışması yönteminden faydalanılan her iki çalışma sonucunda da, kurumlar vergisi indirim açılamasının olay gününde anormal getirileri beraberinde getirdiği sonucuna ulaşılmıştır.

Diğer yandan, hisse senedi piyasasını bir bütün olarak alan ekonomik bazı değişkenlere örneğin enflasyon açıklamalarına (Belen ve Gümrah 2016) yada beklenmedik sosyal yada ekonomik boyutlu olaylara (Mutan ve Topcu 2009) olan tepkisini ölçen çalışmalarda olay çalışması literatürdeki diğer örneklerdir. 
Belen ve Gümrah (2016), 2006-2016 arası aylık tüfe beklenti ve gerçekleşmeleri ile BIST100 verilerini kullanarak yaptıkları çalışmalarında, enflasyon açıklamalarındaki süprizlerin hisse senedi piyasasında anormal getiriler sağladığını fakat sistematik bir şekilde seyretmediğini ve özellikle olay gününde belirgin bir anlamlılığın olmadığı sonucuna ulaşmışlardır.

Mutan ve Topcu (2009) çalışması ise, 1990-2009 tarihleri arasında hisse senedi piyasasının beklenmedik on farklı siyasi ve ekonomik olaya tepkisi ölçülmüş ve getirilerde yaşanan sapmaların büyük, normal olarak beklenen aralığın dışında ve istatistiksel olarak anlamlı olduğu sonucuna varılmıştır.

Bu çalışmanın şekillendirilmesinde, yukarıda özet halinde sunulan literatürün geniş ağından büyük ölçüde faydalanılmıştır. Ancak, yapılan taramada yasal düzenlemelerin olay olarak alındığı örnekler olmasına rağmen, sigorta sektörü üzerine bir çalışmaya rastlanmamıştır. Bu açıdan, çalışmanın yayına değer bulunması halinde ilgili sektöre katkı sağlaması arzu edilmektedir.

\section{Etkin Piyasalar Hipotezi, Firma Değeri ve Yasal Düzenlemeler}

Hisse senedi fiyatlarının piyasadaki geçmiş yada edinilmiş yeni bilgilerden etkilenip etkilenmediği, dolayısıyla bir hafıza yada kural doğrultusunda hareket edip etmediği üzerinde fikir birliğine varılmış değildir. Bu konuda yapılan ilk çalışma, İngiliz hisse senetleri ve emtia fiyatlarını alan Kendall (1953) çalışmasıdır. Kendall, fiyat serilerinin zaman içinde birbirleriyle bağlantılı olmadığını öne sürmüş ve bu bağımsız yapıyı rassal yürüyüş modeli olarak geliştirmiştir (Güngör, 2003, s. 114).

Geçmiş fiyatların gelecek fiyatlar konusunda belirleyici olmadığını öne süren bu modelin üzerine finans literatüründe yeni bir hipotezle yola çıan ise E. Fama'dır. Fama, (1970), piyasanın yeni bilgilere hızla uyum gösterdiğini ve varlık fiyatlarının mevcut tüm bilgileri içerdiğini dolayısıyla ekstra getirilere izin vermediğini belirtmektedir (Çelik ve Taş, 2001, s. 13). Bu yapının ortaya çıktı̆̆ı piyasa ise etkin piyasa olarak adlandırılmaktadır (Fama, 1991, s.155; Fama ve Fisher vd.,1969, s.1).

Fama, etkin piyasa olarak adlandırılan hipotezini tam rekabet koşulları altında çalışan bir piyasa altında şekillendirmiştir. Buna göre, fiyat kabul edici olan çok sayıda alıcı ve satıcı, herhangi bir maliyete katlanmaksızın edindikleri tam bilgiyi rasyonel olarak fayda maksimizasyonu hedeflerine yönelik kullanabilmektedirler (Cootner, 1962, s. 25). Bir başka ifadeyle, piyasa katılımcıları, sahip oldukları bilgileri kullanarak varlığın piyasa değerini elbirliği ile belirlemiş olmaktadırlar. Dolayısıyla, piyasada oluşan fiyatlar, her türlü bilgi ve beklentiyi içermektedirler. Benzer şekilde, piyasaya yeni bir bilgi gelmesi durumunda da, yatırımcılar bu yeni bilgiyi analiz ederek varlık fiyatlarına yine yansitacaklardır (Bayraktar, 2012, s.39; Gümrah ve Belen, 2016, s.429).

Fama'nın (1970) makalesinde yarı güçlü formda etkinlik, 1991 yılındaki makalesinde ise olay çalışması adını alacak olan, yarı güçlü formda piyasa etkinlik ise, varlık fiyatlarının piyasada 
oluşmuş geçmiş bilgilerinin yanısıra kamuya açıklanan ve hisse senedi fiyatına tesir edebilecek olayların da (şirketlerin temettü dağılımı, sermaye artırımları, fiyat/kazanç oranları açıklamaları, kamunun faiz, enflasyon, büyüme vb oran açıklamaları gibi) gecikme olmaksızın fiyatlara yansıdığını ifade etmektedir (Fama, 1970, s. 388). Zayıf formda etkinliği de içeren dolayısıyla ne geçmiş ne de yeni bilgiye dayalı ekstra getiri sağlanamayan bu durumda, ancak içerden sağlanan bilginin şansı olabileceği yorumlanabilir.

Ancak uygulamada, fiyatların tüm bilgiyi yansıtamayabileceğine, tam etkin piyasaların varlı̆ğna dair tartışmalarda sözkonusudur. Bilgi edinmenin maliyeti ve işlem maliyetlerinin varlı̆ğ üzerine oturan ve Grossman ve Stiglitz'in çalışmalarında yer bulan bu öğeler, fiyatların bilgiyi tamamen yansıtmasını zorlaştırmaktadır. (Grossman ve Stiglitz, 1980, s.393). Diğer yandan, yatırımcların her zaman rasyonel kararlar alamayabileceği de, diğer bir sebep olarak gösterilmektedir. Dolayısıyla, tüm bu nedenlere bağlı olarak, varlığın değerinin yatırımcılar tarafından tam olarak tahmin edilemediği ve fiyatların dengeden uzaklaştığı etkin olmayan piyasalardan da literatürde bahsedilebilmektedir (Bayraktar, 2012, s. 40; Kandır ve Yakar, 2012, s. 172-173).

$\mathrm{Bu}$ çalışmada da, sigorta sektör yatırımcısının, firmaların karlılık düzeylerini etkileyebileyecek olması dolayısıyla yakından ilgilendirdiği düşünülen beş yasal düzenlemenin fiyatlara yansıyıp yansımadığı analiz edilmeye çalışılmaktadır.

İlk olay olarak tanımlanan bireysel emeklilik sisteminin getirilmesi ve bu sistemi besleyen köklü değişiklikler olan devlet katkısı (olay 2) ile otomatik katılım (olay 4) sigorta sektörüne yeni fon toplama olanağı yaratması açısından önem arz etmektedir. Bugüne dek hayat sigortacıllğı altında fon toplayıp işleten sektöre daha geniş katılımlı, daha uzun soluklu fon sağlayan ve devlet desteğini de alan bireysel emeklilik sistemi sigorta sektörün genel ekonomideki önemini de artırmaktadır. Genel beklenti, özellikle devlet katkısı ve otomatik katılım ile gelen destekleyici uygulamaların katılımcı sayısını yükseltmesi, yönetilecek fon büyüklüklerini artırması, ölçek ekonomileri ile birim başına maliyelerin düşmesi ve bu alandaki firmaların karlılıklarının artması biçimindedir. Elbetteki sektör yatırımcısı da, yasal düzenlemelerin etkilerini yakından takip ederek değişimlerin etkilerine duyarsız kalmak istemeyecektir.

Sigorta sektöründe halka açık olan yedi şirketten iki tanesi hayat/emeklilik branşında çalı̧ırken diğerleri hayatdışı branşta hizmet vermektedir. Dolayısıyla, sektör yatırımcısı hayatdışı branştaki yasal düzenlemeleri de takip edecektir. Bu doğrultuda, zorunlu olması nedeniyle büyük bir havuzu olan trafik sigortasındaki yine köklü değişimler çalışmanın diğer olaylarıdır.

Şirketleri rekabete zorlayan ve bu nedenle yatırımcı açısından belli ölçüde gelir kaybı riskini taşıyan serbest tarife uygulaması (olay 3) ile belli bir süre için uygulanacak olsada tavan fiyat uygulaması (olay 5) firmaların karlılığını düşürebileceği için, sektör yatırımcısının getiri açısından tedirginlikle izleyecekleri gelişmelerdir. Ancak, tavan fiyat uygulamasında, kaza sayısına bağlı sürekli artan zamlı sigorta primlerinin, iyi sürücüler için ucuz, kötü sürücüler için pahalı bir sistemi beraberinde getirmesi, sigorta şrketlerinin hasar yazdıran sürücüleri bu 
hasara bir ölçüde de olsa ortak ederek kendilerini koruma altına almalarının mümkünlügünü de içermektedir. Dolayısıyla, yatırımcının uygulama hakkında doğru bilgilenmesi, yatırımı konusunda daha doğru karar almasını sağlayacaktır.

\section{Ekonometrik Metodoloji}

\section{Amaç, Kapsam, Veri}

Çalışmanın amacı, bireysel emeklilik ve trafik sigortasına ilişkin bazı yasal düzenlemelerin Borsa İstanbul'da işlem gören sigorta şirketlerinin hisse senedi getirileri aracılığıyla, sektör yatırımcısı için normal üstü getiriler sağlayıp sağlamadığının araştırılmasıdır.

Bu amaçla yukarıda kısaca özetlenen olay çalışması yöntemi kullanılmıştır.

İncelenen literatürde, ilgili sektöre ilişkin herhangi bir çalışmaya rastlanmaması ve sektörün toplumsal önemi çıkış noktasıdır. Çalışma kapsamında, Borsa İstanbul'da payları işlem gören 7 adet sigorta şirketi bulunmaktadır ve şirket listesi, Kamuyu Aydınlatma Platformundan (KAP) edinilmiştir. Şirketlerden, 2 tanesi hayat/emeklilik branşlarında hizmet verirken (Anadolu Hayat ve Emeklilik (ANHY), Avivasa Hayat ve Emeklilik (AVISA)); diğerleri hayatdışı branşlarda çalışmaktadırlar. (Aksigorta (AKGRT), Anadolu Sigorta (ANSGR), Güneş Sigorta (GUSGR), Halk Sigorta (HALKS), RAY Sigorta (RAYSG)).

Şirketlere ilişkin veriler, datastream veritabanı aracılığıyla edinilirken, BIST 100 endeksi için TCMB Elektronik Veri Dağıtım Sisteminden (EVDS) faydalanılmıştır.

Yasal düzenlemelerin sektöre yansımasını görebilmek için şirketlere ilişkin veriler yardımı ile sektör değerleri elde edilmiştir. Bunun için öncelikle şirketlerin aktif büyüklüklerine göre sektördeki ağırlıkları tespit edilmiştir. Her bir şirketin endekslenen fiyat değerleri ile ağırlıkları çarpılmış ve ilgili dönemdeki tüm şirketler için hesaplanan bu değerler toplanarak sektörü anlatan yeni seri oluşturulmuştur. Ayrıca, çalışılan dönem içerisinde piyasaya yeni giren şirketlerin ilgili tarihlerde dahil edilmesiyle değişen ağırlıklara ve böylece elde edilen yeni ve eski serinin birleştirilmesi sürecine de dikkat edilmiştir. Sözkonusu işlemler Halk Sigorta ve Avivasa’nın katıldığı dönemler için de geçerlidir.

Sigorta sektöründeki yasal düzenlemeler içerisinden olay seçimi yapılırken, ele alınan dönem itibariyle firmaların nakit akım değerlerini, karlılıklarını ve getirilerini etkileyebilecek, köklü değişim yaratan ve halen yürürlükte olanlar alınarak, bir seçilim önyargısı oluşturulmamaya da özen gösterilmiştir. Diğer yandan, her ne kadar sektör bazında bir değerlendirme yapılmış olsa da, içinde barındırdığı her bir şirket grubunu doğrudan etkileyecek olaylar olmasına da dikkat edilmiştir. $\mathrm{Bu}$ çerçevede toplam 5 olay (ekde detaylandırılmaktadır) inceleme konusu yapılmıştır.

Çalışmadaki olaylar için şirket bazında da analiz yapılmış olmakla beraber, sektörün geneli üzerine yapılan analizler raporlanmıştır. 


\section{Yöntem}

Olay çalışması, herhangi bir olayın varlık fiyatlarını uzun veya kısa dönemde nasıl ve hangi hızda etkilediği konusunda sonuçlar çıkarılmasını sağlayan ve piyasanın etkinliğini ölçmede kullanılan bir yöntemdir (Badalova vd., 2017, s. 103; Badalova, 2016, s. 45).

Olay çalışması, olayın tanımlanması, olay penceresinin tanımlanması, olayın etkilerinin değerlendirilmesi ve modelin test edilerek sonuçların yorumlanması olmak üzere 4 adımdan oluşmaktadır (Campbell vd, 1997, s.150-152).

İlk aşamada sigorta sektörünün nakit akışını etkileyebilecek olan kanuni düzenlemeler olay olarak seçilmiştir.

Olay çalışmalarının ikinci önemli aşaması olayla ilgili zamanların belirlenmesidir. Zamanlama üç ana zaman bölümünü kapsamaktadır (Kavcar ve Gümrah, 2017, s.106).

Olay günü (zamanı), ilgili olayın gerçekleștiği tarihtir. Kontrol dönemi olarak da tanımlanabilen tahmin penceresi, olayın etkisinin görülmediği dönemdir. $\mathrm{Bu}$ dönemde, varlığın normal getirilerinin hesaplanması sözkonusudur (Çukur ve Eryiğit, 2006, s. 101). Gerçek fiyat hareketlerini tanımlayabilmek için, literatürde 100-300 günlük aralık kullanılmaktadır (Mazgit, 2013, s. 233). Bu çalışmada da, süre 150 gün olarak belirlenmiştir.

Olay penceresi ise, olaydan önceki ve sonraki 3 ila 15 gün arasının alınabildiği bir aralıktır. Olay öncesinin alınması, olay öncesinde olası bilgi sızmalarının fiyatları etkileme ihtimalini ölçmek açısından anlamlıdır (Elbir ve Kandır, 2017, s. 24). Olay sonrası aynı süre ise, olay gerçekleştikten sonra fiyatlara yansımaları görmek açısından yeterli bir süre olarak değerlendirilmektedir (Yazgan, 2017, s.57-58; Mazgit, 2013, s. 233). Çalışmada, olay penceresi,olay tarihinden 10 gün öncesi ve sonrası $(-10,+10)$ olarak belirlenmiştir.

Olay çalışmalarında amaç, olayın olduğu tarihten önceki ve sonraki günlerde, normal üstü getiri (abnormal return, AR) ve kümülatif normal üstü getiri (cumulative abnormal return, CAR) hesaplanmasıdır. Nitekim, piyasanın yeni bilgiye tepkiler vererek fazlalık getiriler yansıttığı varsayılmaktadır.

Normal üstü getirilerin hesaplanabilmesi için ilk olarak gerçekleşen ve beklenen getirin hesaplaması gerekir (Mackinlay,1997, s. 15). Beklenen getirileri hesaplayabilmek için ise piyasa modelinden yararlanıbilir. Piyasa modeli yatırımcıların olay açıklaması nedeniyle olay gününde ve olay gününün öncesi ve sonrasında normal üstü getiriler elde edip etmediklerini belirlemek için kullanılmaktadır (Çukur ve Eryiğit, 2006, s.102; Küçüksille ve Mizrahi, 2015, s. 65; Sakarya ve Sezgin, 2015, s.14).

Bunun için öncelikle, $i$ hisse senedinin $\mathrm{t}$ zamanındaki beklenen getirisinin hesaplanması gerekir: (Mackinlay,1997, s. 18)

$E\left(R_{i, t}\right)=a_{i}+\beta_{i} R_{m t}+e_{i t}$ 
$E\left(R_{i t}\right)$ : i payının t dönemdeki getirisi

$\mathrm{R}_{\mathrm{mt}}$ : BIST 100 endeksinin $\mathrm{t}$ dönemindeki getirisi

$\mathrm{a}_{\mathrm{i}}$ : sabit terim, $\beta_{\mathrm{i}}$ : i payının sistematik riski (eğimi), $\mathrm{e}_{\mathrm{it}}$ :hata terimi

Pazara ilişkin günlük getiri şöyle hesaplanmaktadır. (Henderson,1990, s. 287)

Pazar getiri oranı:

$R_{m t}=\frac{I_{t}-I_{(t-1)}}{I_{(t-1)}}$

$\mathrm{I}_{\mathrm{t}}$ :BIST 100 endeksinin $\mathrm{t}$ günündeki kapanış değerini,

$I_{(t-1)}$ : BIST100 endeksinin t-1 günündeki kapanış değerini göstermektedir.

İkinci aşamada, fiili ve pazar getiri oranları arasındaki fark alınarak normal üstü getiri hesaplanır (Mackinlay,1997, s.19).

Normal üstü getiri= Fiili getiri oranı-Pazar getiri oranı

$A R_{i t}=R_{i t}-E\left(R_{i t}\right)$

$\mathrm{AR}_{\mathrm{it}}=\mathrm{R}_{\mathrm{it}}-\mathrm{a}_{\mathrm{i}}-\mathrm{b}_{\mathrm{i}} \mathrm{R}_{\mathrm{mt}}$

$\mathrm{AR}_{\mathrm{it}}=\mathrm{R}_{\mathrm{it}}-\left(\mathrm{a}_{\mathrm{i}}+\mathrm{b}_{\mathrm{i}} \mathrm{R}_{\mathrm{mt}}\right)$

$A R_{i t}$ : i hisse senedi için $t$ günündeki normal üstü getiri

$\mathrm{R}_{\mathrm{it}}$ : i hisse senedininn $\mathrm{t}$ günündeki gerçekleşen getirisi

$\mathrm{R}_{\mathrm{mt}}$ : Pazar portföyünün $\mathrm{t}$ dönemdeki getirisi

Hesaplanan normal üstü getiriler, sırasıyla birbirleriyle toplanarak, kümülatif normal üstü getiriler (CAR) elde edilir. (Mackinlay, 1997, s. 21)

$C A R_{i t}=\sum_{i}^{N} A R_{i t}$

$\mathrm{AR}_{\mathrm{it}}$ : i hisse senedi için $\mathrm{t}$ günündeki ortalama normal üstü getiri

$\mathrm{CAR}_{\mathrm{it}}$ : i hisse senedi için $\mathrm{t}$ günündeki ortalama normal üstü getirilerin toplamıdır.

$C_{-10,10}=\sum_{t=-10}^{10} A R_{t}$

Olay çalışması yönteminin son aşamasında olay günü ve olay penceresindeki diğer günler için aşağıdaki formül yardımıyla $t$ istatistiği hesaplanır.

$t=\frac{A A R}{S\left(A A R_{t}\right)}$

$\mathrm{t}$ : $\mathrm{t}$ istatistiği, AAR: ortalama anormal getiri, $\mathrm{S}\left(\mathrm{AAR}_{\mathrm{t}}\right)$ : $\mathrm{t}$ günündeki anormal getirinin standart sapmasi

\section{Hipotez}

Yukarıdaki denklemler yardımıyla hesaplanan normal üstü getiriler ve kümülatif normal üstü getirilerin olay penceresi aralığında anlamlı olarak sıfırdan farklı olup olmadığını test edilecektir. Bunun için aşağıdaki hipotezler kurulmuştur.

$\mathrm{H}_{0}$ hipotezi: Getirilen yasal düzenlemenin, sigorta sektörü hisse senedi getirilerine hiçbir etkisi yoktur.

$\mathrm{H}_{0}: \mathrm{AR}, \mathrm{CAR}=0$

$\mathrm{H}_{1}$ hipotezi: Getirilen yasal düzenlemenin, sigorta sektörü hisse senedi getirilerine etkisi vardır. $\mathrm{H}_{1}: \mathrm{CAR}, \mathrm{CAR} \neq 0$ 
Hipotezin kabulu halinde, olayın hisse senedi fiyatlarını etkilediğini söyleyebiliriz yani yatırımclar sektör hisselerinden düzenlemeden kaynaklı normalin üzerinde getiri elde edebilirler (Aygören ve Uyar, 1997, s. 38).

Bu hipotezlerde kullanılan AR ve CAR'ların sıfırdan farklı olup olmadığının tespit edilmesinde t testi kullanılmaktadır (Çukur ve Eryiğit, 2006, s. 103; Koçyiğit, 2008, s. 171).

\section{Bulgular ve Değerlendirme}

Yukarıda belirtilen denklemler yardımıyla, çalışmada olay olarak alınan, sigorta sektörüne ait beş yasal düzenlemenin, önce kanun kabul tarihleri itibariyle, ardından da yürürlüğe girdikleri tarihleri itibariyle $(+10,-10)$ penceresindeki, normal üstü (AR) ve kümülatif normal üstü getirileri (CAR) ile test sonuçları sunulmuştur.

Normal üstü getiriler, yasal düzenlemenin getirilmesinin her bir gün için piyasa değeri üzerindeki etkisini gösterirken; kümülatif normal üstü getiriler toplam etkiyi göstermektedir (Nagm ve Kautz, 2008, s. 70, Elbir ve Kandır, 2017, s.25).

Normal üstü getirilerin pozitif değerleri, olayların yatırımcılar tarafından olumlu algılandığına işaret ederken, negatif değerler tam tersi bilgiyi aktarmaktadır. AR değerlerinin sıfırın etrafında salınımda bulunması ise, düzenlemenin istatistiki olarak etkisinin olmadığı anlamına gelmektedir.

Tablo 1 ve Tablo 2 sirasıly kanun kabul tarihleri itibariyle tekil ve birikimli normal üstü getirileri raporlamaktadır.

Kanun kabul tarihlerinin olay günü olarak alındığı ilk durumda, hiçbir olay için olay gününde anlamlı bir tekil normal üstü getiri ile karşılaşılmamış̧ıı. Diğger yandan, günler itibariyle ortaya çıkan anlamlı tekil anormal getiriler de genel olarak negatif değerler almaktadır.

Birikimli anormal getiriler için, olay gününde analiz sonuçları olay 3 haricinde anlamlı olarak bulunmuştur. Sözkonusu anlamlı etki, olay 1 ve olay 5 için pozitif olarak gerçekleşmişken, diğerlerinde negatif değerler elde edilmiştir. Varolan etkilerin kalıcllğını da izleyebildiğimiz birikimli normal üstü getirilerin ortak noktası, çok düşük değerlerde seyretmesidir.

Sözkonusu yasal düzenlemelerin yürürlüğe girme tarihleri itibariyle yapılan diğer analiz sonuçları ise Tablo 3 ve Tablo 4 ile raporlanmakta ve daha açıklanabilir sonuçlara ulaşıldığı görülmektedir. 
Tablo 1. Olay 1-5 Etrafındaki Tekil Normal Üstü Getiriler ${ }^{2}$

\begin{tabular}{|c|c|c|c|c|c|c|c|c|c|c|}
\hline & \multicolumn{2}{|l|}{ olay 1} & \multicolumn{2}{|c|}{ olay 2} & \multicolumn{2}{|c|}{ olay 3} & \multicolumn{2}{|c|}{ olay 4} & \multicolumn{2}{|c|}{ olay 5} \\
\hline günler & AR & t-ist & AR & t-ist & AR & t-ist & $A R$ & t-ist & $A R$ & t-ist \\
\hline-10 & 0,006 & 0,36 & $-0,007$ & $-1,07$ & $-0,015$ & $-0,64$ & $-0,011$ & $-2,30$ & 0,007 & 0,88 \\
\hline-9 & $-0,001$ & $-0,08$ & $-0,008$ & $-1,17$ & $-0,006$ & $-0,28$ & $-0,001$ & $-0,11$ & 0,000 & 0,02 \\
\hline-8 & 0,031 & 1,85 & 0,004 & 0,55 & $-0,001$ & $-0,05$ & $-0,003$ & $-0,67$ & 0,005 & 0,60 \\
\hline-7 & $-0,012$ & $-0,70$ & 0,010 & 1,54 & 0,033 & 1,44 & 0,002 & 0,41 & 0,004 & 0,51 \\
\hline-6 & 0,046 & 2,80 & $-0,010$ & $-1,41$ & $-0,034$ & $-1,49$ & 0,004 & 0,80 & $-0,001$ & $-0,10$ \\
\hline-5 & 0,034 & 2,03 & 0,000 & $-0,05$ & 0,022 & 0,96 & $-0,007$ & $-1,46$ & $-0,001$ & $-0,18$ \\
\hline-4 & 0,012 & 0,72 & $-0,001$ & $-0,16$ & $-0,005$ & $-0,23$ & $-0,002$ & $-0,38$ & 0,000 & 0,02 \\
\hline-3 & $-0,001$ & $-0,08$ & $-0,006$ & $-0,94$ & $-0,003$ & $-0,12$ & $-0,001$ & $-0,19$ & 0,002 & 0,31 \\
\hline-2 & $-0,014$ & $-0,82$ & $-0,005$ & $-0,76$ & $-0,006$ & $-0,24$ & 0,008 & 1,60 & 0,017 & 2,12 \\
\hline-1 & $-0,002$ & $-0,14$ & 0,006 & 0,84 & $-0,015$ & $-0,65$ & $-0,009$ & $-1,89$ & 0,011 & 1,36 \\
\hline 0 & 0,007 & 0,44 & 0,000 & $-0,07$ & $-0,010$ & $-0,43$ & $-0,001$ & $-0,27$ & $-0,015$ & $-1,89$ \\
\hline 1 & 0,007 & 0,40 & $-0,006$ & $-0,95$ & $-0,012$ & $-0,53$ & 0,002 & 0,53 & $-0,008$ & $-1,03$ \\
\hline 2 & 0,000 & 0,00 & 0,003 & 0,51 & $-0,051$ & $-2,21$ & $-0,007$ & $-1,48$ & 0,012 & 1,49 \\
\hline 3 & $-0,006$ & $-0,39$ & 0,010 & 1,51 & 0,060 & 2,59 & 0,001 & 0,20 & 0,009 & 1,13 \\
\hline 4 & $-0,004$ & $-0,25$ & 0,000 & 0,06 & 0,007 & 0,31 & $-0,006$ & $-1,33$ & $-0,005$ & $-0,58$ \\
\hline 5 & $-0,024$ & $-1,45$ & $-0,001$ & $-0,22$ & 0,017 & 0,72 & 0,006 & 1,31 & 0,005 & 0,64 \\
\hline 6 & $-0,006$ & $-0,37$ & 0,007 & 0,98 & $-0,022$ & $-0,93$ & $-0,002$ & $-0,42$ & $-0,007$ & $-0,87$ \\
\hline 7 & $-0,002$ & $-0,12$ & $-0,014$ & $-2,05$ & $-0,003$ & $-0,14$ & 0,002 & 0,46 & 0,001 & 0,17 \\
\hline 8 & $-0,010$ & $-0,59$ & 0,004 & 0,61 & 0,005 & 0,20 & $-0,002$ & $-0,34$ & 0,003 & 0,40 \\
\hline 9 & $-0,006$ & $-0,38$ & 0,009 & 1,28 & $-0,015$ & $-0,64$ & $-0,001$ & $-0,31$ & $-0,006$ & $-0,69$ \\
\hline 10 & 0,003 & 0,20 & 0,000 & $-0,05$ & 0,000 & $-0,02$ & 0,000 & 0,02 & 0,015 & 1,91 \\
\hline
\end{tabular}

${ }^{2}$ Kanun kabul tarihleri analizinde, olay 3 kanundaki yönetmelik değișikliği ile gerçekleștiğinden Resmi Gazete'de yayın tarihi, olay 5 için ise, istisnai bir durum olarak Resmi Gazete'de yayınlanmadan önce genelgeyle uygulamaya konduğundan yürürlük tarihleri alınmıştır. 
Tablo 2. Olay 1-5 Etrafındaki Birikimli Normal Üstü Getiriler ${ }^{3}$

\begin{tabular}{|c|c|c|c|c|c|c|c|c|c|c|}
\hline \multirow[b]{2}{*}{ günler } & \multicolumn{2}{|c|}{ olay 1} & \multicolumn{2}{|c|}{ olay 2} & \multicolumn{2}{|c|}{ olay 3} & \multicolumn{2}{|c|}{ olay 4} & \multicolumn{2}{|c|}{ olay 5} \\
\hline & CAR & t-ist & CAR & t-ist & CAR & t-ist & CAR & t-ist & CAR & t-ist \\
\hline-10 & 0,006 & 0,17 & $-0,007$ & $-1,17$ & $-0,015$ & $-0,61$ & $-0,011$ & $-1,62$ & 0,007 & 0,53 \\
\hline-9 & 0,005 & 0,13 & $-0,015$ & $-2,44$ & $-0,021$ & $-0,88$ & $-0,011$ & $-1,71$ & 0,007 & 0,54 \\
\hline-8 & 0,035 & 0,99 & $-0,011$ & $-1,84$ & $-0,022$ & $-0,92$ & $-0,015$ & $-2,18$ & 0,012 & 0,90 \\
\hline-7 & 0,024 & 0,66 & $-0,001$ & $-0,17$ & 0,011 & 0,45 & $-0,013$ & $-1,89$ & 0,016 & 1,20 \\
\hline-6 & 0,070 & 1,96 & $-0,011$ & $-1,70$ & $-0,024$ & $-0,96$ & $-0,009$ & $-1,33$ & 0,015 & 1,14 \\
\hline-5 & 0,104 & 2,90 & $-0,011$ & $-1,75$ & $-0,001$ & $-0,05$ & $-0,016$ & $-2,36$ & 0,014 & 1,03 \\
\hline-4 & 0,116 & 3,23 & $-0,012$ & $-1,93$ & $-0,006$ & $-0,27$ & $-0,018$ & $-2,63$ & 0,014 & 1,04 \\
\hline-3 & 0,114 & 3,20 & $-0,018$ & $-2,95$ & $-0,009$ & $-0,38$ & $-0,019$ & $-2,76$ & 0,016 & 1,23 \\
\hline-2 & 0,101 & 2,82 & $-0,024$ & $-3,77$ & $-0,015$ & $-0,61$ & $-0,011$ & $-1,63$ & 0,033 & 2,49 \\
\hline-1 & 0,099 & 2,75 & $-0,018$ & $-2,86$ & $-0,030$ & $-1,22$ & $-0,020$ & $-2,97$ & 0,044 & 3,31 \\
\hline 0 & 0,106 & 2,95 & $-0,018$ & $-2,93$ & $-0,040$ & $-1,63$ & $-0,021$ & $-3,16$ & 0,029 & 2,18 \\
\hline 1 & 0,112 & 3,14 & $-0,025$ & $-3,97$ & $-0,052$ & $-2,13$ & $-0,019$ & $-2,79$ & 0,021 & 1,56 \\
\hline 2 & 0,112 & 3,14 & $-0,021$ & $-3,41$ & $-0,103$ & $-4,22$ & $-0,026$ & $-3,84$ & 0,033 & 2,45 \\
\hline 3 & 0,106 & 2,96 & $-0,011$ & $-1,77$ & $-0,043$ & $-1,77$ & $-0,025$ & $-3,70$ & 0,042 & 3,12 \\
\hline 4 & 0,102 & 2,84 & $-0,011$ & $-1,71$ & $-0,036$ & $-1,47$ & $-0,031$ & $-4,64$ & 0,037 & 2,77 \\
\hline 5 & 0,078 & 2,16 & $-0,012$ & $-1,95$ & $-0,019$ & $-0,79$ & $-0,025$ & $-3,71$ & 0,042 & 3,16 \\
\hline 6 & 0,071 & 1,99 & $-0,006$ & $-0,89$ & $-0,041$ & $-1,68$ & $-0,027$ & $-4,00$ & 0,035 & 2,64 \\
\hline 7 & 0,069 & 1,94 & $-0,019$ & $-3,12$ & $-0,044$ & $-1,81$ & $-0,025$ & $-3,68$ & 0,037 & 2,74 \\
\hline 8 & 0,060 & 1,67 & $-0,015$ & $-2,46$ & $-0,039$ & $-1,62$ & $-0,026$ & $-3,92$ & 0,040 & 2,98 \\
\hline 9 & 0,053 & 1,49 & $-0,007$ & $-1,06$ & $-0,054$ & $-2,22$ & $-0,028$ & $-4,13$ & 0,034 & 2,56 \\
\hline 10 & 0,057 & 1,58 & $-0,007$ & $-1,12$ & $-0,055$ & $-2,24$ & $-0,028$ & $-4,12$ & 0,049 & 3,71 \\
\hline
\end{tabular}

Yasal düzenlemelerin yürürlük tarihlerinden itibaren $(+10,-10)$ penceresindeki, normal üstü (AR) ve birikimli normal üstü getiriler (CAR) test sonuçları sırasıyla Tablo 3 ve Tablo 4 itibariyle sunulmuştur 
Tablo 3. Olay 1-5 Etrafındaki Tekil Normal üstü Getiriler

\begin{tabular}{|c|c|c|c|c|c|c|c|c|c|c|}
\hline \multirow[b]{2}{*}{ Günler } & \multicolumn{2}{|c|}{ olay 1} & \multicolumn{2}{|c|}{ olay 2} & \multicolumn{2}{|r|}{ olay 3} & \multicolumn{2}{|c|}{ olay 4} & \multicolumn{2}{|c|}{ olay 5} \\
\hline & $A R$ & t-ist & $A R$ & $t$ - ist & $A R$ & t-ist & AR & t-ist & AR & t-ist \\
\hline-10 & $-0,001$ & $-0,06$ & $-0,011$ & $-0,55$ & 0,001 & 0,17 & 0,009 & 1,66 & 0,007 & 0,88 \\
\hline-9 & $-0,006$ & $-0,30$ & 0,002 & 0,08 & $-0,002$ & $-0,19$ & $-0,003$ & $-0,52$ & 0,000 & 0,02 \\
\hline-8 & 0,034 & 1,59 & 0,020 & 0,96 & 0,013 & 1,71 & 0,006 & 1,07 & 0,005 & 0,60 \\
\hline-7 & 0,005 & 0,22 & 0,022 & 1,08 & $-0,010$ & $-1,25$ & $-0,002$ & $-0,30$ & 0,004 & 0,51 \\
\hline-6 & 0,036 & 1,71 & 0,031 & 1,51 & 0,013 & 1,60 & 0,008 & 1,42 & $-0,001$ & $-0,10$ \\
\hline-5 & 0,039 & 1,84 & $-0,006$ & $-0,27$ & $-0,001$ & $-0,14$ & 0,011 & 2,09 & $-0,001$ & $-0,18$ \\
\hline-4 & $-0,046$ & $-2,16$ & $-0,006$ & $-0,29$ & $-0,008$ & $-1,06$ & 0,003 & 0,57 & 0,000 & 0,02 \\
\hline-3 & 0,016 & 0,78 & 0,000 & 0,02 & 0,009 & 1,15 & 0,007 & 1,27 & 0,002 & 0,31 \\
\hline-2 & $-0,009$ & $-0,42$ & 0,006 & 0,27 & 0,001 & 0,08 & 0,001 & 0,27 & 0,017 & 2,12 \\
\hline-1 & $-0,009$ & $-0,41$ & $-0,016$ & $-0,80$ & 0,004 & 0,52 & $-0,003$ & $-0,61$ & 0,011 & 1,36 \\
\hline 0 & 0,040 & 1,92 & $-0,001$ & $-0,07$ & $-0,006$ & $-0,75$ & 0,000 & $-0,08$ & $-0,015$ & $-1,89$ \\
\hline 1 & $-0,024$ & $-1,15$ & 0,068 & 3,36 & $-0,013$ & $-1,71$ & 0,001 & 0,25 & $-0,008$ & $-1,03$ \\
\hline 2 & 0,008 & 0,36 & $-0,003$ & $-0,15$ & 0,000 & $-0,06$ & 0,000 & $-0,01$ & 0,012 & 1,49 \\
\hline 3 & 0,011 & 0,54 & 0,023 & 1,14 & 0,007 & 0,93 & 0,005 & 0,86 & 0,009 & 1,13 \\
\hline 4 & 0,010 & 0,49 & 0,000 & 0,01 & $-0,006$ & $-0,77$ & 0,009 & 1,65 & $-0,005$ & $-0,58$ \\
\hline 5 & 0,000 & 0,01 & 0,042 & 2,08 & $-0,004$ & $-0,57$ & 0,005 & 0,84 & 0,005 & 0,64 \\
\hline 6 & 0,011 & 0,52 & $-0,004$ & $-0,17$ & $-0,006$ & $-0,76$ & $-0,012$ & $-2,27$ & $-0,007$ & $-0,87$ \\
\hline 7 & $-0,002$ & $-0,11$ & $-0,003$ & $-0,14$ & $-0,012$ & $-1,51$ & 0,006 & 1,06 & 0,001 & 0,17 \\
\hline 8 & $-0,001$ & $-0,02$ & 0,013 & 0,63 & 0,003 & 0,35 & 0,007 & 1,35 & 0,003 & 0,40 \\
\hline 9 & 0,027 & 1,26 & 0,021 & 1,04 & 0,009 & 1,15 & 0,005 & 0,96 & $-0,006$ & $-0,69$ \\
\hline 10 & 0,003 & 0,14 & $-0,008$ & $-0,38$ & 0,006 & 0,78 & 0,006 & 1,17 & 0,015 & 1,91 \\
\hline
\end{tabular}


Tablo 4. Olay 1-5 Etrafındaki Birikimli Normal üstü Getiriler

\begin{tabular}{|c|c|c|c|c|c|c|c|c|c|c|}
\hline \multirow[b]{2}{*}{ Günler } & \multicolumn{2}{|l|}{ olay 1} & \multicolumn{2}{|c|}{ olay 2} & \multicolumn{2}{|l|}{ olay 3} & \multicolumn{2}{|c|}{ olay 4} & \multicolumn{2}{|l|}{ olay 5} \\
\hline & CAR & t-ist & CAR & $\mathrm{t}$ - ist & CAR & t-ist & CAR & t-ist & CAR & t-ist \\
\hline-10 & $-0,001$ & $-0,03$ & $-0,011$ & $-0,17$ & 0,001 & 0,12 & 0,009 & 0,50 & 0,007 & 0,53 \\
\hline-9 & $-0,008$ & $-0,19$ & $-0,010$ & $-0,14$ & 0,000 & $-0,01$ & 0,006 & 0,34 & 0,007 & 0,54 \\
\hline-8 & 0,026 & 0,63 & 0,010 & 0,15 & 0,013 & 1,18 & 0,012 & 0,67 & 0,012 & 0,90 \\
\hline-7 & 0,031 & 0,74 & 0,032 & 0,47 & 0,004 & 0,31 & 0,010 & 0,57 & 0,016 & 1,20 \\
\hline-6 & 0,067 & 1,62 & 0,063 & 0,93 & 0,016 & 1,42 & 0,018 & 1,00 & 0,015 & 1,14 \\
\hline-5 & 0,106 & 2,56 & 0,057 & 0,84 & 0,015 & 1,32 & 0,030 & 1,63 & 0,014 & 1,03 \\
\hline-4 & 0,060 & 1,45 & 0,051 & 0,76 & 0,007 & 0,58 & 0,033 & 1,80 & 0,014 & 1,04 \\
\hline-3 & 0,076 & 1,85 & 0,052 & 0,76 & 0,016 & 1,38 & 0,040 & 2,19 & 0,016 & 1,23 \\
\hline-2 & 0,068 & 1,64 & 0,057 & 0,85 & 0,016 & 1,44 & 0,041 & 2,27 & 0,033 & 2,49 \\
\hline-1 & 0,059 & 1,43 & 0,041 & 0,60 & 0,020 & 1,80 & 0,038 & 2,08 & 0,044 & 3,31 \\
\hline 0 & 0,099 & 2,41 & 0,040 & 0,58 & 0,014 & 1,28 & 0,037 & 2,06 & 0,029 & 2,18 \\
\hline 1 & 0,075 & 1,82 & 0,108 & 1,60 & 0,001 & 0,09 & 0,039 & 2,14 & 0,021 & 1,56 \\
\hline 2 & 0,083 & 2,00 & 0,105 & 1,55 & 0,001 & 0,05 & 0,039 & 2,13 & 0,033 & 2,45 \\
\hline 3 & 0,094 & 2,28 & 0,128 & 1,89 & 0,008 & 0,70 & 0,043 & 2,39 & 0,042 & 3,12 \\
\hline 4 & 0,104 & 2,53 & 0,128 & 1,90 & 0,002 & 0,17 & 0,053 & 2,89 & 0,037 & 2,77 \\
\hline 5 & 0,104 & 2,53 & 0,171 & 2,52 & $-0,003$ & $-0,23$ & 0,057 & 3,14 & 0,042 & 3,16 \\
\hline 6 & 0,115 & 2,79 & 0,167 & 2,47 & $-0,009$ & $-0,76$ & 0,045 & 2,46 & 0,035 & 2,64 \\
\hline 7 & 0,113 & 2,74 & 0,164 & 2,43 & $-0,020$ & $-1,81$ & 0,051 & 2,78 & 0,037 & 2,74 \\
\hline 8 & 0,113 & 2,73 & 0,177 & 2,62 & $-0,018$ & $-1,57$ & 0,058 & 3,18 & 0,040 & 2,98 \\
\hline 9 & 0,139 & 3,37 & 0,198 & 2,93 & $-0,009$ & $-0,76$ & 0,063 & 3,48 & 0,034 & 2,56 \\
\hline 10 & 0,142 & 3,44 & 0,191 & 2,82 & $-0,002$ & $-0,22$ & 0,070 & 3,83 & 0,049 & 3,71 \\
\hline
\end{tabular}

Olay 1 etrafındaki tekil ve birikimli normal üstü getiriler (AR ve CAR):

Araştırma bulgularına göre, Tablo 1'den görülebileceği gibi, bireysel emeklilik tasarruf ve yatırım sistemi yürürlüğe girmeden önceki 10 günün 5 gününde negatif normal üstü getiriler elde edilirken, bunlardan sadece 4 . gün anlamlı negatif bir etkiye rastlanmaktadır. Düzenleme yürürlüğe girdikten sonraki 10 günde, negatif normal üstü getiri sayısı 3'e düşerken, geri kalan 7 gün de istatistiki anlamlılığı olmasa da pozitif AG'ler elde edilmiştir. Olay tarihinde ise, anlamlılık düzeyi ikiye yakın bir değerle \% 4’lük bir normal üstü getiri sözkonusudur. Olay günü öncesinde yaşanan negatif değerlerin varlığı, her ne kadar uzun süredir bahsi geçse de sistemin nasıl işleyeceğine dair belirsizlikle ilişkilendirilebilir. Kanunun yürürlüğe girmesi ile bu negatif değerlerin azalması da aynı bakış açısıyla açıklanabilir. CAR değerlerine bakıldığında, olay öncesi 5. günde \%10,5 lik anlamlı bir etki yaşanmıştır. Olay günü ise, bu 5. günün değerinin biraz altında \%9,9'luk anlamlı etki yakalanmıştır. Olay sonrası 1. gün haricinde geri kalan 9 günde de anlamlı pozitif değerler artarak devam etmekte ve normal üstü getirilerin kalıcılığına işaret etmektedir. Ancak çok yüksek olmayan değerler, kanunun kabul edilmesine rağmen, yeni emeklilik şirketlerinin 2003 Ekim ayı itibariyle emeklilik planlarını tasdik ettirerek faaliyete geçmeleri ile açıklanabilir. 
Olay 2 etrafındaki tekil ve birikimli normal üstü getiriler (AR ve CAR):

Bireysel emeklilik sisteminde devlet katkısının getirilmesine dair uygulamanın yürürlük tarihinden önceki günlerde, piyasada istatistiksel olarak anlamlı bir etkiye rastlanmamaktadır. Üstelik bu durum, olay günü içinde geçerlidir. Ancak, olay sonrası 1. ve 5. günlerde pozitif anlamlı değerlere rastlanmaktadır. CAR değerlerinde ise, AR değerlerine benzer şekilde olay öncesi yada olay günü herhangi bir hareketlenme görülmezken, anlamlı ve kalıcı etkilerin 5 . günden 10. güne dek sürdüğü görülmektedir.

Olay 3 etrafındaki tekil ve birikimli normal üstü getiriler (AR ve CAR):

Trafik sigortasında sigorta şirketlerinin tarifelerini tam olarak serbest bir şekilde belirleyebileceklerine dair uygulamanın yürürlüğe girmesi ne olay gününde ne de olay öncesi ve sonrasında anlamlı normal üstü getiriler sağlayamamıştır. Üstelik bu durum, kümülatif normal üstü getiriler içinde geçerliliğini korumuştur. Hem tekil hem de birikimli normal üstü getirilerin sıfırın etrafında salınması, ilgili düzenlemeninin herhangi bir normal üstü getiri sağlamadığını işaret etmektedir. Düzenlemenin fiyat rekabetini tetiklemesinin yatırımcıyı tedirgin ederek sektördeki pay getirilerine ilgisini azalttığı düşünülebilir.

Olay 4 etrafindaki tekil ve birikimli normal üstü getiriler (AR ve CAR):

Bireysel emeklilik sistemine getirilen diğer bir yasal düzenleme, sektörü büyük ölçüde hareketlendirmesi beklenen aşamalı olarak uygulanacak olan otomatik katılımdır. Olay gününde sektör piyasalarında herhangi bir etkinin olmadığını gösteren AR değerlerine rağmen, olaydan 5 gün önce yaklaşık \%11'lik anlamlı bir normal üstü getirinin varlı̆̆l, olayın öncesi piyasaya bilginin sızdığını ve ilk etkinin bu gün itibariyle gerçekleştiği biçiminde yorumlanabilir. Aynı olayın kümülatif normal üstü getirilerinin seyrine bakıldığında ise, olaydan 3 gün önce başlayan pozitif ve anlamlı değerlerin olay günü de dahil olmak üzere olaydan sonraki 10. güne dek süreklilik gösterdiğini gözlemlemek mümkündür. Sözkonusu kalıcı etkinin artış eğiliminde olduğunu da belirtmek gerekir. Bu durum, olayın yatırımcı tarafından olumlu karşılandığının bir göstergesi olarak değerlendirilebilir.

Olay 5 etrafındaki tekil ve birikimli normal üstü getiriler (AR ve CAR):

Hayatdışı sigorta branşları içerisindeki ve trafikteki tüm araçları doğrudan ilgilendiren bir diğer düzenleme tavan fiyat uygulamasının yürürlüğe girmesidir. Trafik sigortalarındaki hasar artışı ve vefat tazminatının ödemelerindeki geriye dönük ödemelerin süresi ve itiraza açlk hale gelmesi gibi birçok diğer unsurla artan maliyetin fiyatlara artış olarak yansıyınca tavan fiyat uygulaması gündeme gelmiştir. Bu uygulamanın yürürlüğe girdiği olay günü ve sonrasında anlamlı bir etkiye rastlanamamıştır. Ancak olaydan 2 gün önce, belki de Hazine Müstaşarlı̆̆’ndan yapılan trafik sigortalarında fiyat artışlarının önüne geçilmezse, müsteşarlığın yetkilerini kullanacağı açıklamasının etkisiyle \%1,7 'lik bir anlamlı pozitif normal üstü getiri elde edilmiştir. Uygulamanın kümülatif normal üstü getirilerine bakıldığında, benzer şekilde olay gününden 2 gün önce başlayan ve olay sonrası 1 . gün haricinde anlamlı olan pozitif normal üstü getirilerden bahsedebilmek mümkündür. Tavan fiyat uygulamasına kaba haliyle baktığımızda trafik sigortasında indirimden bahsedilebilir. Oysa, detaya girildiğinde, kaza sayısına bağlı sürekli artan zamlı sigorta primleri ile aslında, iyi sürücüler için ucuz, kötü 
sürücüler için pahalı bir sistemi beraberinde getiriyor. $\mathrm{Bu}$ durum, sigorta şirketlerinin kendilerine hasar yazdıran sürücüleri bu hasara ortak etmesi biçiminde okunursa, şirketleri gelir kaybına uğratmayan bir uygulama olarak değerlendirilebilir. Dolayısıyla da, yatırımcı açısından tedirgin edici bir gelişme olarak yorumlanmayabilir.

\section{Sonuç}

Bu çalışmanın amacı, sigorta sektörüne yönelik beş yasal düzenlemenin Borsa İstanbul'da işlem gören sigorta şirketlerinin hisse senedi getirileri aracıllğıyla, sektör yatırımcısı için normal üstü getiriler oluşturup oluşturamadığının test edilmesidir.

Bu etkinin ölçülmesi amacıyla da, olay çalışması analiz yöntemi olarak benimsenmiştir. Kanun kabul tarihleri ve yürürlüğe girme tarihleri olarak iki farklı tarihin olay günü olarak seçildiği çalışmada, kanun kabul tarihlerinde anlamlı etkiler gözlemlenmemiştir.

Yürürlük tarihlerinin esas olarak ele alındığı analiz sonuçlarına göre, sektörü ilgilendiren beş olay içerisinde, sadece trafik sigortasında tam serbest tarifeye geçilmesi durumunda, getirilen yasal düzenlemenin, sigorta sektörü hisse senedi getirilerine hiçbir etkisinin olmadığını belirten $\mathrm{H}_{0}$ hipotezinin kabul edildiği görülmüştür. Buna göre, olay 3 etrafında sigorta sektöründe, uygulama ile ortaya çıkan fiyat rekabetinin yatırımcıyı tedirgin ederek pay getirilerine ilgiyi azalttığı ve normal üstü getirilerin oluşmadığı söylenebilir.

Diğer tüm olaylarda ise, yasal düzenlemelerin kimi zaman olay öncesinde kimi zaman ise olay gününde normal üstü ve kümülatif normal üstü getiriler sağladığı gözlemlenmiştir. Bu durum, olay 1-2-4 ve 5 için getirilen yasal düzenlemelerin, sigorta sektörü hisse senedi getirilerine etkisi var biçiminde şekillenen sıfırdan farklı hipotezin kabulüne işaret etmektedir. Ayrıca, yukarıda olaylar etrafındaki AR ve CAR değerleri yorumlanırken de görüldüğü gibi,elde edilen sonuçlar, düzenlemelerin sektöre olası etkilerine dair beklentilerle de uyumludur.

Normal koşullarda düzenlemenin gündeme girdiği an veya en azından kanunlaştığ 1 anda fiyatların anlamlı tepki vermemesi etkin piyasalar açısından bilginin fiyatlara yansıma hızı bakımından sorunlu olacaktır. Teknik olarak etkin olmayan piyasa olarak değerlendirilebilecek bir durum geçmişi otuz yılı bulan bir borsa için çok normal görülen bir durum değildir. $\mathrm{Bu}$ açıdan hisse fiyatlarının neden ilk anda değilde, uygulamaya girmesinden sonra tepki verdiğinin analizi gelecek çalışmaların ilgi alanı olması gerekir. 


\section{Kaynakça}

Aygören, H., Uyar, S. (1997). İstanbul Menkul Kiymetler Borsası'nda (İMKB) Denetim Görüşlerinin Hisse Senedi Getirileri Üzerindeki Etkisi. İMKB Dergisi, 9(36), 31-45.

Babacan, B., Özer, G. (2013). Şirketlerin Gönüllü Açıklamalarının Hisse Senedi Getirileri Üzerine Etkileri.Yönetim ve Ekonomi, 20(2), 91-104.

Badalova, L. (2016). Aracı Kurum Tavsiyelerinin Hisse Senedi Değeri Üzerine Etkisi.(Yayımlanmamı̧̧ yükseklisans tezi). Hacette Üniversitesi / Sosyal Bilimler Enstitüsü, Ankara.

Badalova, L., Yıldız, Y. ve Karan, M.B. (2017). Aracı Kurum Tavsiyelerinin Hisse Senedi Fiyatı Üzerindeki Etkisi: Türkiye Örneği. Muhasebe ve Finansman Dergisi, Nisan, 97-119.

Bayraktar, A. (2012). Etkin Piyasalar Hipotezi. Aksaray Ü. İIBF Dergisi, 4(1), 37-47.

Campbell, J.Y., Lo A. W. L. ve Mackinlay A. C. (1997). The Econometrics of Financial Markets. New Jersey: Princeton University Press

Çelik, T. T., Taş, O. (2007). Etkin Piyasa Hipotezi ve Gelişmekte Olan Hisse Senedi Piyasaları. İTÜ Sosyal Bilimler Dergisi, 4(2), 11-22.

Çevikçelik, S. (2012). Şirket Birleşmelerinin Firmanın Piyasa Değerine Etkisi: İMKB'de Bir Uygulama. (Yayımlanmamış yükseklisans tezi). Adnan Menderes Üniversitesi / Sosyal Bilimler Enstitüsü, Aydın

Cootner, P. H. (1962). Stock Prices: Random Walk vs. Systematic Changes. Industrial Management Review, Spring, 24-45.

Çukur, S., Eryiğit, R. (2006). Banka Birleşme ve Devralma Olaylarının Borsadaki Etkisi. İktisat, İsletme ve Finans, 21(243), 96-107.

Çukur, S., Eryiğit, R. (2007). Yatırım Ortaklıkları ve Bedelsiz Sermaye Artırımları: İMKB’de Ampirik Bir Analiz. İktisat İşletme Finans, 22(254),73-85.

Elbir, G., Kandır, S. Y. (2017). Yatırım Duyurularının Pay Getirileri Üzerindeki Etkisinin İncelenmesi: Demir-Çelik Sektörü Örneği. Ekonomi Bilimleri Dergisi, 9(1), 16-32.

Fama, F. E., Fisher, L., Jensen, C. M. \& Roll, R. (1969). The Adjustment of Stock Prices To New Information. International Economic Review, 10(1), 1-21.

Fama, E.F. (1970). Efficient Capital Markets: A Review of Theory and Emprical Work. Journal of Finance, 25(2), 383-417.

Fama, E. F. (1991). Efficient Capital Markets: II. The Journal of Finance, 46(5), 1575-1617. 
Grossman, S. ve Stiglitz, J. (1980). On The Impossibility Of Informationally Efficient Markets. American Economic Review, 70(3), 393-408.

Gümrah, Ü., Belen, M. (2016) Türkiye'de Hisse Senedi Piyasası'nın Enflasyon Açılamalarındaki Süprizlere Tepkisi. İnsan ve Toplum Araştırmaları Dergisi, 5(3), 109-133.

Güngör, B. (2003). Finans Literatüründe Anomali Kavramı ve Etkin Piyasalar Hipotezi. Atatürk Ü. İIBF Dergisi, 17(1-2), 109-133.

Güre, D. P., Kütük, S. (2016). Türkiye'de Kurumlar Vergisi Değişikliğinin Hisse Senedi Fiyatlarına Kısa Dönemli Etkisi. Ankara Üniversitesi SBF Dergisi, 71(1) , 303-322.

Güvercin, A., Demir, Y. (2015). Kazanç Açıklamaları ve Şirket Değeri İlişkisi: BIST 100 Şirketleri Üzerine Bir Olay Analizi. Eskişehir Osmangazi Ü. İIBF Dergisi, 10(3), 233 253.

Hekimoğlu, M.H., Tanyeri, B. (2011). Türk Şirket Birleşmelerinin Hisse Senedi Fiyatları Üzerindeki Etkileri. Erişim Tarihi: 12.07.2017, http://ssrn.com/abstract=1768015 http://dx.doi.org/10.2139/ssrn.1768015

Henderson, G. V. (1990). Problems and Solutions In Conducting Event Studies. The Journal of Risk and Insurance, 57(2), 282-306.

Kamuyu Aydınlatma Platformu. https://www.kap.org.tr

Kandır, S.Y.,Yakar, S. (2012). Kurumlar Vergisi Oranındaki Değişikliğin Hisse Senedi Getirileri Üzerindeki Etkisinin İncelenmesi. Maliye Dergisi, 163, 170-186.

Kavcar, B., Gümrah Ü. (2017). Borsa İstanbul'da Kurumsal Yönetim İlkelerine Uyum ve Firma Değeri: Olay Çalışması. AİBÜ Ekonomik ve Sosyal Araştırmalar Dergisi, 13(1), 103 114.

Koçyiğit, M., Kılıç A. ( 2008). Leasing Sektöründe KDV Oranı Değişikliğinin İMKB'de İşlem Gören Leasing Şirketlerinin Hisse Denedi Getirilerine Etkisi. Erişim tarihi: 10.10.2017, http:journal.mufad.org.tr, 165-174.

Küçüksille, E., Mizrahi R. (2015). Bedelli Sermaye Artırımı Duyurularının Halka Açık İşletmelerin Hisse Senedi Performanslarına Etkisi: Borsa İstanbul'da Bir Araştırma. KMÜ Sosyal ve Ekonomik Araştırmalar Dergisi, 17(29), 63-69.

Mackinlay, A. C. (1997). Event Studies In Economics And Finance. Journal of Economic Literature, $X X X V(1), 13-39$.

Mazgit, İ. (2013). Endeks Kapsamında Olmanın Hisse Senedi Getirilerine Etkisi: BIST Temettü 25 Endeksi Üzerine Bir Uygulama. Sosyoekonomi, 20(20), 225-264. 
Mutan, C. O., Topcu, A. (2009). Türkiye Hisse Senedi Piyasasının 1990-2009 Tarihleri Arasında Yaşanan Beklenmedik Olaylara Tepkisi. Sermaye Piyasası Kurulu Araştırma Raporu.

Şahin, A., Doğukanlı, H. (2015). Banka Birleşme ve Satın Alma Duyurularının Hedef Banka Hisse Senedi Fiyatları Üzerine Etkileri. Finans Politik ve Ekonomik Yorumlar, 52(600), 9-25.

Sakarya, Ş. (2011). İMKB Kurumsal Yönetim Endeksi Kapsamındaki Şirketlerin Kurumsal Yönetim Derecelendirme Notu ve Hisse Senedi Getirileri Arasındaki İlişkinin Olay Çalışması Yöntemi İle Analizi. ZKÜ Sosyal Bilimler Dergisi, 7(13), 147-162.

Sakarya, S.., Sezgin, H. (2015). Sendikasyon Kredisi Kullanımının Bankaların Hisse Senedi Getirilerine Etkisi:Olay Çalışması Yöntemiyle BIST’te Bir Uygulama. TBB Bankacılar Dergisi, 26(92), 5-24.

Şimşir, Ş. A. (2017). Birleşme ve Devirler Türk Alıcı ve Hedef Şirketler İçin Ekonomik Değer Yaratıyor Mu? Sabancı Üniversitesi Araştırma Raporu, Erişim tarihi:01.10.2017, http://cef.sabanciuniv.edu/wp-content/uploads/2016/02/CEF ARASTIRMARAPORU_TR_052017.pdf

TC. Merkez Bankası Veri Bankası, evds.tcmb.gov.tr

Yazgan, K.F. (2017). Kurumsal Yönetim Derecelendirmesinin Hisse Senedi Performansına Etkisi: BIST Kurumsal Yönetim Endeksi Üzerine Bir İnceleme, (Yayımlanmamış yükseklisans tezi), Balıkesir Üniversitesi / Sosyal Bilimler Enstitüsü, Balıkesir.

Yılmaz, M. (2010). Şirket Birleşme ve Devralmalarının Getiri Üzerinde Etkisi ve İMKB'de Bir Uygulama, (Yayımlanmamış doktora tezi), Kadir Has Üniversitesi / Sosyal Bilimler Enstitüsü, İstanbul. 


\section{Ek: Çalışmada Ele Alınan Olaylar}

İnceleme konusu olaylara ilişkin bilgilendirme aşağıdaki gibidir.

Olay 1: Bireysel emeklilik sistemi: Bireysel emeklilik sisteminde, bireysel emeklilik fonu altyapısı oluşturulması, kayıtlılık ve tahsilat artırıcı tedbirlerin alınması gibi konular ilgili kanun ile 2000 yılında başbakanlığa gelmiş ve 07.10.2001 itibariyle yürürlüğe girerek uygulama alanı bulmuştur.

Bireysel Emeklilik Tasarruf ve Yatırım Sistemi Kanunu (BES Kanun no: 4632)

Kanun kabul tarihi :28.03.2001

Yürürlük tarihi :07.10.2001

Resmi Gazete yay. tarihi :07.04.2001 (Resmi Gazete no: 24366)

Olay 2: Bireysel emeklilikte devlet katkısı: Bireysel emeklilikteki değişiklikleri, destekleri içeren paketle gündeme gelen devlet katkısı , sisteme dahil olanların devletin \%20 lik vergi teşviğini belli koşullarda doğrudan nakit olarak alabilecekleri dair bir uygulama olarak 01.01.2013 itibariyle yürürlüğe girmiştir.

Bireysel Emeklilik Tasarruf ve Yatırım Sistemi Kanunu ile Bazı Kanun ve Kanun Hükmünde Kararnamelerde Değişiklik Yapılmasına Dair Kanun (Kanun no: 6327)

(Resmi Gazete no :28338 madde 29, ek madde 1 ile devlet katkısı açıklanmaktadır.)

Kanun kabul tarihi :13.06.2012

Yürürlük tarihi :01.01.2013

Resmi Gazete yay. tarihi :29.06.2012

Olay 3: Trafik sigortasında tam serbest tarife: Hazine tarafından sigorta şirketlerinin görüşüne önceden sunulmuş olan, trafik sigortasının hem primlerinde hem de şartlarında yapılacak değişiklikler bir yönetmelikle toplanarak 01.01.2014 de yürürlüğe sokulmuştur. Yeni uygulama ile artık şirketlerin, trafik sigortası primlerini tam bir serbestlik içinde belirleyecekleri ve internet siteleri üzerinden açıklama zorunluluğunun getirilmiştir.

Resmi Gazete yay.: 19.06.2013 (Resmi Gazete no: 28682)

Yürürlük tarihi : 01.01.2014

Olay 4: Bireysel emeklilikte otomatik katılım: Birçok uilkede uygulanan işverenlerin çalışanlarını işe başlatırken otomatik olarak BES sistemine dahil ettiği uygulamanın ilk ayağının yürürlük tarihi 01.01.2017’dir.

Bireysel Emeklilik Tasarruf ve Yatırım Sistemi Kanununda Değişiklik Yapılmasına Dair Kanun (Kanun no: 6740)

Kanun kabul tarihi : 10.08.2016

Yürürlük tarihi :01.01.2017 
Resmi Gazete yay. tarihi :25.08.2016 (Resmi Gazete no:29812)

Olay 5: Tavan fiyat uygulaması: Hazine, zorunlu trafik sigortası primlerindeki artışa karşı tavan fiyat uygulamasını getirmiş ve uygulama 12.04.2017 itibariyle yürürlüğe girmiştir.

(Tavan fiyat uygulmasının yasal sürecinde istisnai bir durum olarak resmi gazetede yayınlanmadan önce genelgeyle uygulamaya konmuştur. Genelgeye göre Başbakan yardımcısı Mehmet Şimşek'den alınan 10.04.2017 tarihli onayla 12.04.2017-31.12.2017 tarihleri arasında uygulanmak üzere tavan fiyat genelgesi çıkartılmıştır.

Genelge no ve tarih: 2017/1 10.04.2017

Resmi Gazete yay tarihi: 3.05.2017 (Resmi Gazete sayı: 30055 (Karayolları Motorlu Araçlar Zorunlu Mali Sorumluluk Sigortasında Tarife Uygulama Esasları Hakkında Yönetmelikte Değişiklik Yapılmasına Dair Yönetmelik) Trafik sigortası poliçelerine ilişkin primlerin tespitine dair geçici madde eklenmiş ve tavan fiyat uygulaması anlatılmıştır.)

Yürürlük tarihi: 12.04.2017 